\title{
CONCEPTUAL METAPHORS USING ENGLISH NAUTICAL EXPRESSIONS
}

\author{
Ngo Thi Nhan* \\ Faculty of Foreign Studies, Vietnam Maritime University, \\ 484 Lach Tray street, Ngo Quyen district, Hai Phong city \\ Received 19 August 2019 \\ Revised 28 October 2019; Accepted 22 December 2019
}

\begin{abstract}
This study was conducted to investigate metaphors relating to nautical expressions. Among a number of approaches, cognitive semantics introduced by Saeed (2005) is adopted in this study. Besides, the insight into metaphor in terms of image schemata mainly has its foundation from the theory of conceptual metaphors established by Lakoff and Johnson (1980).The sentences containing nautical expressions with their metaphorical meanings were collected from maritime newspapers, magazines, books, websites, etc. and analyzed in terms of image schemata by the quantitative, qualitative, analytic, and descriptive methods. The findings reveal that the image schemata in nautical expression based metaphors are much diversediverse but uneven.
\end{abstract}

Keywords: conceptual metaphors, nautical expressions, image schemata

\section{Introduction}

In the "Metaphors We Live By" (1980: 8), Lakoff and Johnson confirmed "metaphor is not the device of the poetic imagination and the rhetorical flourish" or "a matter of the extraordinary" but a subject of ordinary language that "is perceptions and understanding". Indeed, thousands of metaphorically used words can be found in our everyday language which, for some reason, are not acknowledged of. Speakers of English seem to get so familiar with such expressions as "the head of the state", "the key of the success", "the foot of the hill", etc. that they hardly recognize the words "head", "key", and "foot" in the above examples are used metaphorically.

Likewise, the language of seafarers, maritime economists, maritime journalist, etc., is filled with metaphors. Such metaphorical expressions as launch, fit out, and anchor in

\footnotetext{
Tel.: 84-983226880
}

Email : nhannt.nn@vimaru.edu.vn the following examples "launch a project", "fit out the Maritime Museum", "anchor at the Museum" are very popular in maritime newspapers, magazines, journals, websites, and daily life of sailors. Obviously, the study of metaphor cannot be restricted to the study of literature only as some linguists state. Instead, it should also be the study of language teaching and learning because a good understanding of how metaphors work in daily life, according to Cobuild (1999), is very important for learners of English to increase their vocabulary, comprehend new or original metaphors, and make use of metaphors in English.

This research is implemented to find out the structures of experience or image schemata that motivate the formation of metaphors using nautical expressions. These findings are expected to assist students in Navigation Department, VIMARU with the comprehension and utilization of metaphors in nautical expressions.

With such aims, this study is to find the answer to the following questions: 
- Which image schemata motivate metaphors in nautical expressions?

- What is the frequency of each image schema extended in these expressions?

- What metaphorical concepts are formed from this structure of experience?

The answer to these questions will expose which facts in the working environment of those people in marine field have greater effects on the formation of nautical expressionbased metaphors.

\section{The theoretical framework}

\subsection{Cognitive semantics}

Cognitive semantics is part of the cognitive linguistics movement. The main tenets of cognitive semantics are, first, that grammar is conceptualization; second, that conceptual structure is embodied and motivated by usage; and third, that the ability to use language draws upon general cognitive resources and not a special language module.

Meanwhile, cognitive semantic theories are typically built on the argument that lexical meaning is conceptual. Meaning in cognitive semantics "is based on conventionalized conceptual structures, thus semantic structure, along with other cognitive domains, reflects the mental categories which people have formed from their experience of growing up and acting in the world" (Saeed, 2005, p.44) . One of the conceptual structures and processes given special attention to in cognitive semantics is conceptual metaphor.

\subsection{Conceptual metaphors}

Conceptual metaphor in cognitive semantics will be relevant to my study in which experiential structure will be applied to the corpus of analysis. As a result, this part will be started with the definition of conceptual metaphor. Afterwards, its aspects, target and source domain and its most important characteristic, systematicity, will be introduced. The basis for the construction of metaphor, image schemata will be discussed at the end of this section.

\subsubsection{Definition of conceptual metaphors}

Originally, metaphor was a Greek word meaning "transfer". The Greek etymology is from meta, implying "a change" and herein meaning "to bear, or carry". During the first half of the twentieth century, metaphor was just studied at the level of literal referents (referentalist view) or changing of meaning or sense (descriptivist view). In the late 1970s, linguists such as Lakoff, Johnson, and Reddy began to realize that metaphor was not only extremely common, but also related to thought and action. Indeed, they claimed that "our conceptual system is fundamentally metaphoric in nature" (Lakoff \& Johnson, 1980, p.8). Furthermore, metaphor is not particularly about language at all, but rather about thought. Therefore, they defined metaphor as "the expression of an understanding of one concept in terms of another, where there is some similar or correlation between the two" or the "understanding and experiencing one kind of thing in terms of another." (Lakoff and Turner, 1980, p.135)

Take the metaphorical concept ARGUMENT IS WAR that Lakoff and Johnson explained in Metaphor We Live by (1980) as an example. ARGUMENT is expressed in expressions of WAR because there is a correlation between these two expressions. Expressions like Your claims are indefensible; He attacked every weak point in my argument; His criticism was right on the target, etc. are examples of the metaphors which reveal the above underlying metaphorical concept. We see the person we are arguing with as an opponent. We attack his oppositions and we defend our own. We gain and lose ground. We plan and use strategies. If we find a position indefensible, we can abandon it and take a new line of attack. Many of the things we do in arguing are partially structured of an argument: attack-defend, counter-attack, etc. reflect this. 
It is very important to make a distinction between metaphor and simile. These two tropes are often mentioned together as examples of rhetorical figures. Metaphor and simile are both expressions that describe a comparison; the only difference between a metaphor and a simile is that a simile makes the comparison explicit by using "like" or "as".

Saeed (2005, p.345) explained the difference as "a simile states that $A$ is like $B$, a metaphor states that $A$ is $B$ or substitutes $B$ for $A$." According to this definition, then, "You are my sunshine" is a metaphor whereas "Your eyes are like the sun" is a simile.

\subsubsection{Target Domain and Source Domain} of Conceptual Metaphor

Conceptualist views consider metaphor as a cognitive mechanism used to structure our knowledge in the mind by means of one domain of experience understood in terms of another domain. The nature of this metaphor is explained following a mapping process from a source domain onto a target domain. "The domain that is mapped is called the source domain, and the domain onto which the source is mapped is called the target domain " (Saeed, 2005, p.346). Richards (1936) calls them the tenor and the vehicle.

Take the metaphor "That woman is a witch" as an example. The source domain in this example is $a$ witch and the target domain is that woman. Normally, a witch is thought of as an ugly and cruel woman having magic powers and doing evil things. That woman is seen to share some common features with a witch such as ugly, cruel, doing evil things. The metaphor is formed on this basis.

Similarity may be concluded mistakenly to be the basis for the formation of metaphors. However, to look more deeply into the nature of metaphor, cognitive linguists find out that the original basis of metaphor is our conceptual structure.

About the nature of conceptual structure, it can be seen that conceptual metaphors are "not just linguistic expressions of a specific kind, but conceptual structures". (Leezenberg, 2001, p.315) Such structures are an irreducible part of the way in which we conceptualize the world. According to Lakoff and Johnson (1980), conceptual structure is "embodied" in so far as it rises from "preconceptual experience". Preconceptual experiences, again, are structured in terms of basic-level structure which associated with basic-level categories characterized by gestalt perception, mental imagery, and motor movements and roughly correspond to "image schemata". These schemata are skeletal images that we use in cognitive operation. We have many image schemas. These schemata are discussed in more detail in the next part because they relate directly to my analysis.

\subsubsection{The Systematicity of Conceptual Metaphor}

According to conceptualist views, we think and act in terms of conceptual system. Our conceptual system is largely metaphorical in nature; therefore, metaphorical concept is systematic and the language we use to talk about that aspect of the concept is systematic, too. The systematicity here refers to "the way that a metaphor does not just set up a single point of comparison features of the source and target domain are joined so that the metaphor may be extended, or have its own internal logic". (Saeed, 2005, p.348)

It can be seen in the ARGUMENT IS WAR metaphor that expressions from the vocabulary of war such as attack a position, indefensible, strategy, new line of attack, win, gain ground, etc., form a systematic way of talking about the battling aspects of arguing. It is no accident that these expressions mean what they mean when they are used to talk about arguments. A portion of the conceptual network of battle partially characterizes file concept of an argument, and the language follows suit (Lakoff \& Johnson, 1980).

Another metaphorical concept suggested by Lakoff and Johnson (1980) is TIME IS MONEY. Time in a valuable commodity. It is a limited resource that they use to 
accomplish their goals. Because of the way that the concept of work has developed in modern Western culture, where work is typically associated with the time it takes and time is precisely quantified, it has become customary to pay people by the hour, week, or year. Corresponding to the fact that they act as if time is a valuable commodity, a limited resource, even money, they conceive of time that way. Thus they understand and experience time as the kind of thing that can be spent, wasted, budgeted, invested wisely or poorly, saved, or squandered. Therefore, the conceptual network of money characterizes the concept of time and it is realized in many linguistic expressions.

TIME IS MONEY:

You are wasting my time.

This gadget will save you hours.

I don't have the time to give you.

2.2.4. Image schema in conceptual metaphors

According to experientialist with Lakoff and Johnson as the most typical representatives, image schemata structure many of our metaphorical concepts. They are basic units of representation, grounded in the experience of human body.

An image schema is considered "an embodied prelinguistic structure of experience that motivates conceptual metaphor mappings" (Saeed, 2005:353).

The above definition confirms the fact that image schemata are an important form of conceptual structure. The basic idea is that "because of our physical experience of being and acting in the world - of perceiving the environment, moving our bodies, exerting and experiencing force, etc. - we form basic conceptual structures which we then use to organize thought across a range of more abstract domains" (Saeed, J., 2005, p.353). In brief, metaphors are formed by the expansion of image schemata by a process of metaphorical extension into abstract domain.

Lakoff and Johnson (1987) provided a list of image schemata. Among them, the major ones introduced by Saeed (2005: 353-357) include:

- Containment Schema (C): we have experiences of being physically located ourselves within bounded locations like rooms, beds, etc. and also putting objects into containers. This result is an abstract schema of physical containment. This schema of containment can be expanded by a process of metaphorical extension into abstract domains. For example, THE VISUAL FIELD IS CONTAINER, as in:

The ship is coming into view.

He is out of sight now.

There is nothing in sight...

- Path Schema (P): everyday, we move around the world and experience the movements of other entities. Our journeys typically have a beginning and an end, a sequence of places on the way and direction. Other movements may include projected paths, like the flight of a stone thrown through the air. Path schema based on such experience contains a starting point, an end point, and a sequence of contiguous locations connecting them.

E.g.: The metaphorical concept LIFE IS A JOURNEY derives from this schema:

Giving the children a good start in life.

Are you at a crossroad in your life?

Her career is at a standstill.

- Force Schema (F): this schema is held to arise from our everyday experience as we grew as children, of moving around our environment and interacting with animate and inanimate entities.

- Compulsion: the basic force schema where a force acts on an entity, take the metaphorical concept LOVE AS A PHYSICAL FORCE as an example:

I was magnetically drawn to her.

They gravitated to each other immediately.

His whole life revolves around her.

They lost their momentum.

- Counterforce: a counterforce schema is a force that involves the active meeting of 
physically or metaphorically opposing forces. For example, the experiences of football players and participants in a head-on auto collision.

- Blockage: a force schema in which a force is physically or metaphorically stopped or redirected by an obstacle. For example, the experience of a crawling baby encountering a wall is stopped or redirected by the wall.

- Removal of Restraint: a force schema that involves the physical or metaphorical removal of a barrier to the action of a force, or absence of a barrier that was potentially present.

- $\quad$ Part-Whole Schema (PW): this schema of our body is connected with the experience of our own bodies as organized wholes including parts. According to Lakoff (1987), a part-whole schema is an image schema involving physical or metaphorical wholes along with their paths and a configuration of the parts. For example, our body is the physical whole together with its parts. This experience leads to the metaphorical concept that Company is whole and its members are parts:

A framework for the political body

He is the head of Human Resources Department.

That company is the business and finance heart of the city.

- Source-Path-Goal Schema (SPG): is connected with the concept of oriented motion and consists of an initial place called source and a destination called goal connected by a path. This schema underlies the abstract metaphorical valued concept of purpose, which is grounded in our experience of reaching a goal.

- Orientation Schema (O): this schema relates to the structure and functioning of the body in its form. We are oriented in three dimensions: the up-down orientation, the front-back orientation, and the right-left orientation. The orientation up, front, and tight usually associated with positive values and vice verse, the orientation down, back, and left usually relate to negative values. That is the explanation for such metaphors as He is the head of the state.

\subsection{Componential analysis}

If semantics components serve as material to analyze metaphors in nautical expressions, componential analysis will serve as a tool.

Actually, componential analysis is a "way of formalizing, or making absolutely precise, the sense relations that hold between words." (Lyons, 1996: 107) In this method, sense or meaning of words is examined under the view of component parts commonly referred to as semes. It is sometimes called decomposition of the sense of the word. For example, the words 'nephew' and 'niece' both denote human beings. However, the sense of each word can be represented as followed :
(1) Nephew = [human]
(2) Niece $=$ [human]
[male]
[female]

$\begin{array}{ll}\text { [relative }] & {[\text { non-adult }]} \\ \text { [relative } & {[\text { non-adult }]}\end{array}$

We can develop the formalization a little further. We can abstract the negative

component prom [non-adult]and replace it with the negation-operator. Now we have:
(1) Nephew
$=\quad[$ human $] \quad[+$ male $]$
[relative] [-adult]
(2) Niece
$=\quad[$ human $] \quad[$-male $]$
[relative] [-adult]

There are two related reasons for identifying such components. Firstly, according to Lyons (1996) they may allow an economic characterization of

the lexical relation. Secondly, they form part of our psychological architecture and provide us with a unique view of conceptual structure. 


\subsection{Nautical Expressions in English}

With two main islands and a lot of small ones, the United Kingdom has a very long coastline. Its marine may have been developed as early as 45,000 years ago marked by the first seaworthy boat. The long-standing history of Maritime is also shared by many other English speaking countries including America and Australia whose first settlers were sea-born immigrants. If you happen to visit an English speaking country and listen to their conversation, you will soon deduce the fact that the inhabitants were of an essentially seafaring stock because language is the great mirror of a nation's habits and history. Although the soldier, the farmer, the lawyer, the hunter, the merchant, and many others have contributed liberally from their special vocabularies to the common storehouse of daily speech, the wealth of English words and phrases supplied by the sailor is enormous.

Nautical expressions are the expressions relating to sea, ship, and sailing. However, not just learners of English but even native speakers who know little about sailing will find some nautical expressions completely idiomatic. They use these expressions in their daily life without knowing that they were woven into land from the sea. For example, the common adjectives "first-rate", "second-rate"... come down to us from the fives rates or sizes of warships, a classification which was in use as early as the Restoration. Even before that time, "flotsam" (floating wreckage) had been coupled to "jetsam" (cargo thrown overboard) in the well known equivalent for odds and ends. The complaint we usually hear in the times of high prices "to make ends meet" originates in the troubles of the sailor who tried to keep the ends of all ropes securely whipped with twine. According to Batchelder (1929), three-fourth of the sea expressions in our conversation are used in total unconsciousness of their meaning and origin. If we trace back to their original meaning, we will easily find that the meanings of these words were formed due to the trope called metaphor. These metaphors own their existence to sailors and those who know a bit about sailing. A learner of English, if can gain understanding of these expressions, will find such nautical expressions much richer and more interesting and certainly more memorable, too.

\section{Research design and methodology}

\subsection{Data collection and methodology}

Sixty-five sentences containing nautical expressions with metaphorical meanings are collected from marine websites, newspapers, magazines, books, etc. to serve as the materials for analysis in my study. In this way, the natural and practical manner of the material will reinforce the accuracy of the results.

The main methods applied in this research are descriptive, analytic, quantitative and qualitative. The descriptive method is used in order to find out the answer to the first study question about the image schemata motivated in metaphorical concepts in maritime field.. Analytic method is also necessary as this study concerns with the analysis of the formation of metaphorical concepts in maritime field. Quantitative method is applied to locate the frequency and proportion of each image schema presented in the metaphorical concepts. And it is qualitative in that the insights into metaphorical concepts using maritime expressions will be achieved from reading the materials and documenting the statistics.

\subsection{Data analysis}

The theory of image schemata by Lakoff \& Johnson (1980) is applied to categorize metaphors in the nautical expressions chosen. Firstly, the experiences depended on to form the image schema are given. Secondly, the metaphorical concepts raised from the experiences are shown. Finally, the kinds of image schema that the metaphors belong to are stated. For example, let us have a look at the expression "to throw overboard" used to express the state of "being sacked" in the following sentence "He has been thrown overboard due to his inability for the work." 
- Actual experience forming the schema: the metaphor is this case is motivated by the experience: people are physical objects contained on board ships. Being thrown overboard is a bad luck and, to sailors, is a kind of punishment.

- Metaphorical concept: a ship is a company, the containment for employees. So that being thrown overboard (out of the containment) is being sacked from the company.

- Motivating schema: metaphors formed in this way, according to Lakoff \& Johnson (1980) are motivated by containment schema.

Similar analyses were done to the sixtyfive expressions to classify their image schemata. The theory of componential analysis by Lyons (1996) was also utilized to facilitate the analyses of metaphors in those expressions such as when indentifying the sense of the original expressions or explaining the meanings of metaphorically used expressions.

Sixty-five tokens were divided into six groups. The first group, expressions relating to ship and sailor's movement, includes sixteen expressions. The second group, expressions relating to ship's maneuver contains eighteen expressions. The other eight expressions belong to the third group of expressions relating to ship's position and situation. Five expressions were analyzed in the fourth group named expressions relating to ship's structure and organization. The fifth group with ten expressions relating to the sea and the weather was also taken into consideration. The final group, expressions relating to ship's structure and organization, accounts for nine expressions. In the following six sub-parts, the results of the analyses done to each group are presented.

\subsubsection{Expressions Relating to Ship and} Sailor's Movement

Sixteen expressions relating to the movement of ship and sailor in sixteen sentences were analyzed in this part. The occurrence of each image schema in this group is shown in Table 1 below:

Table 1. Image Schemata in Ship and Sailor's Movement Expressions

\begin{tabular}{|c|c|c|}
\hline Image schema & Expressions used/ Total & Percent \\
\hline C & $9 / 16$ & $56 \%$ \\
\hline P & $8 / 16$ & $50 \%$ \\
\hline F & $1 / 16$ & $0.6 \%$ \\
\hline PW & $0 / 16$ & $0 \%$ \\
\hline SPG & $0 / 16$ & $0 \%$ \\
\hline O & $0 / 16$ & $0 \%$ \\
\hline
\end{tabular}

Containment schema is expanded the most frequently in this group (56\%). Expressions relating to ship and sailor's movement are mainly verbs which show the movement of physical objects on to and out of ship and the movement of the ship at sea. These experiences mainly raise the image of containers. For example, in the following sentences taken from a website, sea is regarded as another space, the website. Website users moving inside the web page are considered ships moving at sea:
Ahoy lads! Where do you want to go?

\section{Homeport}

Go astern

Full ahead - Next nautical Yarn Sriram's Home on the net

\section{Cruise back to Sailorschoice.com}

A ship goes astern means that it goes towards its stern. A website user goes astern in the web page means that he goes backward to the previous page. Similarly, he/ she goes to the next page is to go full ahead. The image of ship cruising back to a place that it berthed 
raises the image of a website user coming back to the webpage that he/ she retrieved. Therefore, the webpage is the container for the website user, just as the sea is the container for the ship to move in. The process of forming these metaphorical concepts can be explained as followed:

- Actual experience forming the schema: ships are physical objects moving at sea just like moving in a container.

- Metaphorical concept: many other spaces such as websites are the containers like the sea. The people moving in these spaces are ships.

- Motivating schema: Containment

The schema that occupies the second biggest percentage of occurrence in this group is path schema $(50 \%)$. This fact is owing to a very similar experience among seafarers: each voyage has its starting point (departure), end point (arrival), and a sequence of contiguous locations (ports of call, islands...). This process of a voyage gives seafarers the image of life or love as in the following sentences:

Our love is making headway.

They don't know where their life will drift.

Our love relationship is swinging with wind and tide.

She has always had brains, looks and luck. She has just sailed through life.

A ship making headway means that it is moving ahead smoothly. A love is making headway means that it is in good progress. If a ship is drifting, it is moving along the water current without control. A life which has no orientation or direction is conceptualized as a ship drifting at sea. In the last sentence, love, again, is conceptualized as a ship in rough sea. A ship sails through life means that it sails with great ease. If a person sails through life, he/ she can make progress in life with little effort. Below is process forming the metaphors of the above expressions:
- Actual experience forming the schema: the image of sea voyages: each voyage has its starting point (departure), end point (arrival), and a sequence of contiguous location (ports of call, islands...)

- Metaphorical concept: love and life are voyages. Implementing a job is taking a voyage. When two people fall in a passionate love, they sink into it. Their love may make headway (make progress), drift (break), or swing with wind and tide (have difficulty). A person may make progress in life with great ease (sail through life). A project has its starting point when it is embarked and then it gets under way, which means that all the steps are taken to implement it.

- Motivating schema: Path

Besides, some expressions expressing the movement ship, which are motivated by containment schema, can also be motivated by force schema. Therefore, force schema also occupies a certain percentage though very small $(0.6 \%)$ in this group. As I mentioned above the expression to swing with wind and tide was motivated by containment schema. However, the below explanation shows that it is also motivated by force schema:

- Actual experience forming the schema: the force of the wind and tide makes the ship at sea swing.

- Metaphorical concept: relationships are ships which are also affected by the force of the wind and tide.

- Motivating schema: Force

\subsubsection{Expressions Relating to Ship's} Maneuver

Eighteen expressions relating to ship's maneuver in eighteen sentences are dealt with in this part. The frequency of each image schema in this group is shown in the below table: 
Table 2. Image Schemata in Ship's Movement Expressions

\begin{tabular}{|c|c|c|}
\hline Image schema & Expressions used/ Total & Percent \\
\hline C & $0 / 18$ & $0 \%$ \\
\hline P & $0 / 18$ & $0 \%$ \\
\hline F & $0 / 18$ & $0 \%$ \\
\hline PW & $0 / 18$ & $0 \%$ \\
\hline SPG & $18 / 18$ & $100 \%$ \\
\hline O & $1 / 18$ & $0,6 \%$ \\
\hline
\end{tabular}

One hundred percent of the metaphors in this group are expanded by source-path-goal schema. The process of maneuvering a ship has its source from the point that the ship berths. Different techniques of navigation make up the image of a path, and the last port of call is the goal that marks the success of the maneuver. The first technique that new sailors have to memorize is Learning the ropes (learn the whole rope system of the ship). However, if a recruit of any company learns the rope, it means that he/she tries to get familiar with the job. The sailor who is in the bridge and steers the wheel is taking the helm or at the helm. In the following sentences, the two expressions take the helm and at the helm respectively carry the metaphorical meanings: to take control and to be the boss.

We cannot take the helm because there are too many competitors.

Only he can make decision whether to sell the product because he is at the helm.

The last technique that a helmsman has to perform to finish the voyage is to berth the ship. If he berths the ship successfully, it means that he achieves the goal. Therefore, if we say, "the development of the company berthed on the shore", we mean that the company achieved its goal of development. The process of constructing the above metaphors can be explained as below:

- Actual experience forming the schema: the process and different techniques and action taken to maneuver the ship from the departure port to the arrival port. The goal to achieve is to maneuver the ship safely to the last port.
- Metaphorical concept: implementing a work is maneuvering a ship. Leading a life is also maneuvering a ship. The boss is the helmsman. He has the right to set the sail and pick the course. A recruit must learn the ropes. The work may go on smoothly and the company can operate on its own steam. Sometimes, there may be difficulties and another tack must be tried. If the company successes, it means that it berths the shore. Your life is also maneuvered. It may be steered on course (on the right way) or off course...

- Motivating schema: Source-Path-Goal

The analyses to the expressions in this group also reveal an interesting point that source-path-goal schema is usually combined with orientation schema. For instance, in the case of the expression on course and off course, which are used to denote the direction of a ship, in the following sentences:

Regardless of where you were headed before, it is never too late or too early to get your life on course.

That unfaithful man steered her life off course.

During the voyage, which serves as the path of the schema, the helmsman steers the ship and keeps it on course (on the direction that has been fixed), not let it off course. However, on course and off course are also the expressions that denote the orientation. In the above sentences, on course and off course are conceptualized as the lifeline. A life on course is a good life, vice versa, a life off course is a bad life. As a result, these two metaphors are motivated by two image schemata at the same 
time: source-path-goal and orientation. This explains a small percentage that orientation schema occupies in this group $(0,6 \%)$. The formation of those metaphors can be clearly explained as followed:

- Actual experience forming the schema: the direction that the ship must keep to during the voyage.

- Metaphorical concept: good is on course, bad is off course.

- Motivating schema: Source-Path-Goal, Orientation

\subsubsection{Expressions Relating to Ship's} Position and Situation

The analyses were done to eight expressions in this section to find out the frequency of each image schema. The results are presented in Table 3:

Table 3. Image Schemata in Ship's Position and Situation Expression

\begin{tabular}{|c|c|c|}
\hline Image schema & Expressions used/ Total & Percent \\
\hline $\mathrm{C}$ & $2 / 8$ & $25 \%$ \\
\hline $\mathrm{P}$ & $0 / 8$ & $0 \%$ \\
\hline $\mathrm{F}$ & $0 / 8$ & $0 \%$ \\
\hline $\mathrm{PW}$ & $4 / 8$ & $50 \%$ \\
\hline $\mathrm{SPG}$ & $0 / 8$ & $0 \%$ \\
\hline $\mathrm{O}$ & $4 / 8$ & $50 \%$ \\
\hline
\end{tabular}

Metaphors in this group are motivated by both part-whole and orientation with equal percentage $(50 \%)$. Containment schema also plays rather important in the metaphors of this group (25\%). Let us have a look into the detailed analyses of some expression in this group.

The expression athwardships means across the widest part of the ship. This expression is used metaphorically in the sentence "What are the issues athwardships your economy at the moment?". This metaphor is formed by the motivation of two schemata, which are explained below:

- Actual experience forming the schema: the distance across the ship from side to side, different position on board ships.

- Metaphorical concept: economy is containment as ship, across the ship is a long side the economy. Athwardships is prevailing.

- Motivating schema: Orientation, Containment

This example, once more, confirms the spontaneous appearance of containment schema and orientation schema in a metaphor.
Similar case is also found in the expression on deck in the sentence "the baseball umpire calls the next batsman on deck". The batsman on deck is the man that must get ready for the next ball. The motivation process of the two image schemata in this expression is shown below:

- Actual experience forming the schema: on an important position on board ship

- Metaphorical concept: baseball field is containment as ship, on deck is on the position ready to do the task given

- Motivating schema: containment, Orientation

Some other expressions which are also motivated by orientation schema include athwardships, on deck, aloft, and bottom of the ship's social ladder. The formation of metaphors using these expressions can be:

- Actual experience forming the schema: different positions on board ships.

- Metaphorical concept: athwardships is prevailing, on deck or aloft is good, and at the bottom is bad.

- Motivating schema: Orientation 


\subsubsection{Expressions Relating to Ship's Structure and Organization}

Five expressions were studied and brought about the below results:

Table 4. Image Schemata in Ship's Structure and Organization Expressions

\begin{tabular}{|c|c|c|}
\hline Image schema & Expressions used/ Total & Percent \\
\hline C & $0 / 6$ & $0 \%$ \\
\hline P & $0 / 6$ & $0 \%$ \\
\hline F & $0 / 6$ & $0 \%$ \\
\hline PW & $5 / 6$ & $83.3 \%$ \\
\hline SPG & $0 / 6$ & $0 \%$ \\
\hline O & $1 / 6$ & $16.6 \%$ \\
\hline
\end{tabular}

Part-whole is still the pervasive schema in this group (83.3\%). Besides, only another schema extended in the metaphors in this group is orientation $(16.6 \%)$. This is due to the concept that ship is complete object and its organization is in a very neat order. The formation of the metaphorical concepts in this group is pointed out below:

- Actual experience forming the schema: the ship as a whole and the function of its different parts and manning.

- Metaphorical concept: The organization of ship's manning is that of a nation. The functions of different parts of a ship are the functions of things in life.

- Motivating schema: Part-Whole

Take the expression figurehead whose literal meaning is carved wooden decoration, often female or bestial, found at the prow of ships as an example. This expression shows an object in the whole structure of a ship.
Furthermore, only one metaphor in this group is motivated by orientation schema portside (the left-right side of a ship). The orientation schema motivates the metaphor using this expression in the following way:

- Actual experience forming the schema: the left-right side of a ship

- Metaphorical concept: left side (portside) is minor. Right side (starboard side) is major

- Motivating schema: Orientation

That concept leads to the metaphor in the below sentence:

Those of us on the portside of the political ship might ask a similar question about the effect of division and enmity in the national discourse.

3.2.5. Expressions Relating to the Sea and the Weather

Ten expressions were analyzed in this part, which brings aboutthe following results:

Table 4. Image Schemata in Ship's Structure and Organization Expressions

\begin{tabular}{|c|c|c|}
\hline Image schema & Expressions used/ Total & Percent \\
\hline C & $4 / 10$ & $40 \%$ \\
\hline P & $0 / 10$ & $0 \%$ \\
\hline F & $5 / 10$ & $50 \%$ \\
\hline PW & $2 / 10$ & $20 \%$ \\
\hline SPG & $0 / 10$ & $0 \%$ \\
\hline O & $0 / 10$ & $0 \%$ \\
\hline
\end{tabular}

Force schema occupies half of the metaphors in this group. Four over ten expressions are used to realize metaphorical concepts in the following way: 
- Actual experience forming the schema: physical force of the seawater and the weather (wind, rain...)

- Metaphorical concept: feeling is physical force of the seawater and the weather

- Motivating schema: Force

To make it clear, let us have a look at the following example:

The power and energy of love waved into everyone.

The image of the force of seawater washing the shore raises the metaphorical concept about love among seafarers. The force of love is conceptualized as physical force of the seawater. As a result, it waves into everyone.

Containment schema also plays a crucial role in motivating metaphors in this group $(40 \%)$. The process of forming those metaphors is shown below:

- Actual experience forming the schema: large and deep spaces where ships sail.

- Metaphorical concept: the image of container with a great amount of things inside.

- Motivating schema: Containment

The large sea and ocean raise the image of great quantity as in the phrases "An ocean of sound" and "a river of words". Some other objects are also conceptualized in this way are islands, sea... In Part-Whole schema occupies $20 \%$ of the schemata in this group. Its motivation can be explained as followed:

- Actual experience forming the schema: different images of the sea and its water

- Metaphorical concept: different sea states are different feelings

- Motivating schema: Part-Whole

This process can be seen in the below metaphor:

Few pages feel wavy at touch like someone read it with wet hands.

It centers around the stormy marriage of the young couple.

Wavy is a state of the seawater. In the above sentence, it is used to denote a kind of feeling. In this case, an abstract target domain "feeling" is conceptualized in expressions of a physical object wave. The second expression stormy is in the same situation as the expression wavy.

3.2.6. Expressions Relating to Ship Building and Ship's Procedure

The analyses are done to eight expressions in this part to find out the frequency of each image schema. The results are shown in Table 6:

Table 6. Image Schemata in Ship Building and Ship's Procedure

\begin{tabular}{|c|c|c|}
\hline Image schema & Expressions used/ Total & Percent \\
\hline $\mathrm{C}$ & $0 / 8$ & $0 \%$ \\
\hline $\mathrm{P}$ & $0 / 8$ & $0 \%$ \\
\hline $\mathrm{F}$ & $1 / 8$ & $12.5 \%$ \\
\hline $\mathrm{PW}$ & $3 / 8$ & $37.5 \%$ \\
\hline SPG & $4 / 8$ & $50 \%$ \\
\hline $\mathrm{O}$ & $0 / 8$ & $0 \%$ \\
\hline
\end{tabular}

The process of building a ship with many steps structures the source-path-goal schema in this group. That is the explanation for the $50 \%$ that this schema occupies. The detailed explanation is presented below:

- Actual experience forming the schema: steps in the process of building ships
- Metaphorical concept: the process of building a ship is the process of implementing a project

- Motivating schema: Source-Path-Goal

All the preparations for building a ship make up the source of the schema. For example, building the ship on the stock first, 
then launch it into water. This experience brings the metaphors in the following sentence:

The project that had long been on the stocks was finally launched.

If a project is on the stocks, it is in the preparation stage. When that project is launched, each step of the project is implemented.

Part-Whole schema occupies nearly $40 \%$ of all the schemata in this group. It mainly relates to the expression of ship's procedure. Its motivation is carried out as below:

- Actual experience forming the schema: procedure relating to the clearing in or clearing out of ships

- Metaphorical concept: the function of each procedure is the function of people in life

- Motivating schema: Part-Whole

In the case of the expressions pilot and port in the following sentences:

God is my pilot.

I will rest in the port of God forever.

Pilot is the person who helps the ship into or out of port. God is conceptualized as a pilot because in maritime, the role of the pilot is very important. Port is place that can release seafarers after many difficulties of each voyage. Therefore, port is conceptualized as heaven.

Another schema expanded in the group, though seldom, is force schema $(12.5 \%)$. It motivates the formation of metaphor in the sentence below:

The irate father threatens to give his young a keelhauling.

The work of hauling the keel of a ship with scraper is very hard and energy consuming. The keel of the ship is like the spine of a person. Therefore, the act of cleaning the keel of a ship is compared to that of a spine. A father threatens to give his young a keelhauling means that he threatens to give him a very savage punishment. The motivation of force schema in this expression can be seen below:

- Actual experience forming the schema: the force used to make the ship's keel clean

- Metaphorical concept: the force used to do the hard work is compared to the savage of the punishment

- Motivating schema: Force

\section{Discussion}

In the previous part, the expressions chosen were analyzed in terms of image schemata. The frequency of each schema in each group of expressions was summed up. In this part, before going into the detail of each image schema, I would like to have a look at the overall picture of image schemata used in the sixty-five nautical expressions chosen. Two tables below are designed to supply readers with a better view. The first one is the sum-up of the frequency of each kind of image schema. The second is the sum-up of the frequency of image schema in each group of expressions.

Table 7. The Frequency of Image Schema

\begin{tabular}{|c|c|c|}
\hline Image schema & Expressions used/ Total & Percent \\
\hline C & $15 / 65$ & $23 \%$ \\
\hline P & $8 / 65$ & $12.3 \%$ \\
\hline F & $10 / 65$ & $15.3 \%$ \\
\hline PW & $14 / 65$ & $21.5 \%$ \\
\hline SP & $22 / 65$ & $33.8 \%$ \\
\hline O & $6 / 65$ & $9.2 \%$ \\
\hline
\end{tabular}


Table 8. The Frequency of Image Schema in each Group of Expressions

\begin{tabular}{|c|c|c|c|c|c|c|c|c|c|c|c|c|}
\hline \multirow[t]{2}{*}{$\begin{array}{l}\text { Image } \\
\text { Schema }\end{array}$} & \multicolumn{2}{|c|}{$\begin{array}{c}\text { Ship and } \\
\text { Sailor's } \\
\text { Movement }\end{array}$} & \multicolumn{2}{|c|}{$\begin{array}{c}\text { Ship } \\
\text { Maneuver }\end{array}$} & \multicolumn{2}{|c|}{$\begin{array}{c}\text { Ship's } \\
\text { Position \& } \\
\text { Situation } \\
\end{array}$} & \multicolumn{2}{|c|}{$\begin{array}{c}\text { Ship's } \\
\text { Structure \& } \\
\text { Organization }\end{array}$} & \multicolumn{2}{|c|}{$\begin{array}{c}\text { Sea \& } \\
\text { Weather }\end{array}$} & \multicolumn{2}{|c|}{\begin{tabular}{|c|}
$\begin{array}{c}\text { Ships' } \\
\text { Procedure \& } \\
\text { Building }\end{array}$ \\
\end{tabular}} \\
\hline & Total & $\%$ & Total & $\%$ & Total & $\%$ & Total & $\%$ & totar & $\%$ & Total & $\%$ \\
\hline $\mathrm{C}$ & $9 / 15$ & & $2 / 1$ & & $0 / 15$ & & $0 / 15$ & $0^{\circ}$ & & & $0 / 15$ & $0 \%$ \\
\hline$P$ & $6 / 6$ & $100 \%$ & $0 /$ & $0 \%$ & $0 / 6$ & $0 \%$ & $0 / 6$ & $0 \%$ & $0 / 6$ & $0 \%$ & $0 / 6$ & $0 \%$ \\
\hline $\mathrm{F}$ & $1 / 7$ & $14 \%$ & $0 / 7$ & $0 \%$ & $0 / 7$ & $0 \%$ & $0 / 7$ & $0 \%$ & $5 / 7$ & $72 \%$ & $1 / 7$ & $14 \%$ \\
\hline PW & $0 / 14$ & $0 \%$ & & $0^{\circ}$ & $4 / 14$ & $29 \%$ & $5 / 14$ & $36 \%$ & $2 / 1$ & $14 \%$ & $3 / 14$ & $21 \%$ \\
\hline SPG & $0 / 22$ & $0 \%$ & $18 / 22$ & 82 & $0 / 22$ & $0 \%$ & $0 / 22$ & $0 \%$ & $0 / 22$ & $0^{\circ}$ & $4 / 22$ & $18 \%$ \\
\hline $\mathrm{O}$ & $0 / 6$ & $0 \%$ & $1 / 6$ & $17 \%$ & $4 / 6$ & $67 \%$ & $1 / 6$ & $17 \%$ & $0 / 6$ & $0 \%$ & $0 / 6$ & $0 \%$ \\
\hline
\end{tabular}

\subsection{Containment schema}

According to the data in table 7 above, this schema stands at the second position after Source-Path-Goal schema in the virtue of frequency $(23 \%)$. It means that the image of the sea and the ship as containers has great effect on the concepts of seafarers. This schema is mainly extended in expressions relating to the movement of the ship and the sailor $(60 \%)$, expressions relating to the sea $(27 \%)$, and expressions relating to ship maneuver (13\%). The reason is that ship moving or maneuvered at sea is moving or maneuvered in a container. Sailors move onto or out of ship which is conceptualized as a container for them. As a result, the source domain for metaphors motivated by this schema is mainly ship and sea. That is the reason why we have such metaphorical concepts as SEA IS CONTAINER and SHIP IS CONTAINER.

\subsection{Path schema}

Path schema takes $12.3 \%$ among six image schemata analyzed. Expressions relating to the movement of ships and sailors during a voyage are the main device to extend this schema. In the marine field, the image that gives the deepest impressions of a path is a sea voyage. This image is the source domain for many metaphorical concepts, for example, LIFE IS A SEA VOYAGE and LOVING RELATIONSHIPAS TRIPAT SEA, which are realized in six chosen expressions of ship and sailor's movement (to make headway, sink, drift, swing, sail through life, sail against the wind, embark, and get under way). Besides, the target domains of these metaphors are mainly abstract domain such as life and loving relationship.

\subsection{Force schema}

The force of the sea is the main experience structuring the force schema extended in maritime register. Metaphorical concepts motivated by force schema are realized by $72 \%$ of the expressions relating to the strength of seawater. This source domain is normally used to conceptualize abstract target domain, such as love in the concept LOVE IS SEA or emotion in A SOUL TROUBLED BY EMOTION IS STORMY SEA and HUMAN EMOTION IS SEA, or attitude in OUR ATTITUDE IS FATE OF THE SEA.

\subsection{Part-Whole schema}

Part-whole schema is also extended frequently in metaphors based on nautical expressions $(21.5 \%)$, this due to the concept that the physical objects used in maritime should be watertight ones. These objects include many parts organized orderly. The schema is used rather evenly among the expressions of six groups. However, the most frequent one is still group four: expressions relating to the structure of the ship (36\%). This schema is also combined with force schema 
to form metaphors in marine field (in the case of the expression undertow and stormy). Two common metaphorical concepts motivated by this schema are NATION IS A SHIP and ENTERPRISE IS A SHIP.

\subsection{Source-Path-Goal Schema}

This schema is expanded the most regularly in maritime field because the working environment of seafarers requires the clear identification of the source, the path, and the goal of each task. For example, maneuvering a ship includes identifying obviously where, when, and how to set the sail, which course to pick for the whole voyage, when to reach the port of call, etc. The main source domain used to form metaphors using this schema is the process of maneuvering a ship and the process of building a ship. Typical metaphorical concepts motivated by this schema are BUSINESS ENVIRONMENT IS SAILING, BUILDING A SHIP IS IMPLEMENTING A PROJECT, etc.

\subsection{Orientation schema}

Orientation schema is not expanded very frequently. It is mainly realized by the expressions relating to the ship's position. This due to the fact that most of the expressions used to show the direction of the ship are not marine origins; therefore, the presence of expressions showing orientation is limited. However, Orientation schema is normally combined with Source-Path-Goal and Containment schema to motivate metaphors (in the case of the expressions on course, off course, athwardwhips, and on deck). One typical concept motivated by this schema is STARBOARD SIDE IS MAJOR, PORTSIDE IS MINOR.

\section{Conclusion}

In this paper, sixty-five nautical expressions have been investigated in the virtue of image schema. The three research questions were addressed with a clear answer: the image schemata expanded in maritime field to form metaphors are much diversified but their frequencies are not even.

Besides, the study also indicated that:

- The image schema varies due to the minor fields of the metaphorical expressions. For example, in the field of shipbuilding, source-Path-Goal schema pervades but in the field of ship movement, Containment Schema prevails.

- Two image schemata may be expanded spontaneously to form a metaphor, especially the combination of Containment and Orientation schema.

The findings of this paper suggest the teachers of ESP in navigation Department, Vietnam Maritime University, with a new way of teaching metaphorical expressions to students. If teachers are supplied with the information about image schemata in nautical terms, they can make metaphorical expressions much more interesting and memorable to students. For example, instead of merely introducing that the expression to give a wide berth can be used with the metaphorical meaning to keep a distance with somebody, the teacher may explain the experience structure, the metaphorical concept, and the image schema underlying this metaphorical expression. In this way, students can understand the cognitive process of English seafarers, which can greatly assist their comprehension and utilization of metaphors in English.

However, the issue raised in this paper has still left much to be studied. Firstly, only more than sixty expressions were analyzed, which is a small number in comparison with the big treasure of nautical expressions. Secondly, the cultural factor, which influences the preconceptual experiences, has not been addressed in this paper. Finally, the method of identifying the image schema is limited by the researcher's ability to recognize the structure 
of experience in English people's mind.

Is this the only way to look into metaphors?

The answer is not at all. There are many other ways that are enough to keep any researcher occupied for ages. I highly recommend a study into doing contrastive analyses between metaphors using nautical expressions in English and Vietnamese because as denoted in the study by Hoa, P.V. \& Thu, H. (2017) that the distinctions in "culture, lifestyle and thought" are the causes of the differences in metaphorical expressions in languages".

\section{References}

Batchelder, S.F. (1929). Some Sea Expressions in Land Speech. The New England Quarterly, 2(4), 625-653. Cobuild, C. (1999). English Guides Metaphor. Ho Chi Minh City: Ho Chi Minh Press.
Corbert, E. \& Connors, R. (1999). Classical Rhetorical for the Modern Student. Oxford: Oxford University Press.

Lakoff, G. \& Johnson, M. (1980). Metaphors We Live By. Chicago and London: University of Chicago Press.

Lakoff, G. (1987). Women, fire, and dangerous things. Chicago: The Univ. of Chicago Press.

Lakoff, G. \& Turner, M. (1989). More than Cool Reason: A field Guide to Poetic Metaphor. Chicago: University of Chicago Press.

Leezeberg, M. (2001). Contexts of Metaphor. Oxford: Elsevier.

Lyons, J. (1996). Linguistic Semantics. Cambridge: Cambridge University Press.

Phan Van Hoa \& Ho Thi Quynh Thu (2017). Poetic Metaphors of Love in English and Vietnamese. $V N U$ Journal of Foreign Studies, 33(6), 56-64.

Richards, I.A. (1936). The philosophy of Rhetoric. Oxford: Oxford University Press.

Saeed, J.I. (2005), Semantics. Oxford: Blackwell Publishing.

\title{
ẨN DỤ Ý NIỆM SỬ DỤNG TƯ NGỮ TIẾNG ANH NGÀNH HÀNG HẢI
}

\author{
Ngô Thị Nhàn \\ Khoa Ngoại ngũ, Trường Đại học Hàng hải Việt Nam, \\ 484 Lạch Tray, quận Ngô Quyền, Thành phố Hải Phòng
}

Tóm tắt: Bài nghiên cứu được thực hiện nhằm tìm hiểu về lối nói ẩn dụ có liên quan đến các thuật ngữ trong ngành hàng hải. Có rất nhiều phương thức tiếp cận nghiên cứu về lối nói ẩn dụ, tuy nhiên trong nghiên cứu này phương thức tiếp cận được chọn là đuờng hướng của ngữ nghĩa tri nhận được giới thiệu bởi Saeed vào năm 2005. Bên cạnh đó, lối nói ẩn dụ được nghiên cứu theo khía cạnh sơ đồ hình ảnh dựa trên lý thuyêt ẩn dụ ý niệm do Lakoff và Johnson giới thiệu năm 1980. Những câu có xuất hiện các thuật ngữ hàng hải với nghĩa ẩn dụ được lựa chọn từ các tạp chí, báo, sách và trang web trong ngành hàng hải, sau đó được phân tích theo sơ đồ hình ảnh bằng phương pháp định tính, định lượng, giải thích và mô tả. Kết quả phân tích cho thấy các loại sơ đồ hình ảnh được sử dụng để hình thành lối nói ẩn dụ sử dụng thuật ngữ hàng hải rất đa dạng nhưng lại không đồng đều.

Tù khóa: ẩn dụ ý niệm, thuật ngữ hàng hải, sơ đồ hình ảnh 